\title{
WHAT DOES IT TAKE TO CLIMB THE LADDER? (A SIDEWAYS APPROACH)*
}

\author{
Mauro Luiz Engelmann** \\ mauroengelmann@gmail.com
}

RESUMO O objetivo deste artigo é mostrar que as interpretações "tradicional" e "resoluta" não livraramo "Tractatus" da aparente autoderrota paradoxal. Argumento que essas leituras apresentam apenas uma nova roupagem ao paradoxo. A leitura "tradicional" de Hacker acaba atribuindo uma conspiração metafísica ao "Tractatus", o que é incompativel com os objetivos do livro. A leitura "resoluta" de Diamond e Conant atribui a Wittgenstein uma conspiração autoral, o que contradiz suas opiniões sobre autoria e método. Com base nas dificuldades encontradas em ambos os lados do debate atual, concluo este artigo propondo vários requisitos que a correta interpretação do "Tractatus" deve preencher.

Palavras-chave Wittgenstein, “Tractatus”, leitura resoluta, paradoxo, Kierkegaard.

ABSTRACT The aim of this paper is to show that "traditional" and "resolute" interpretations have not freed the "Tractatus" from the apparent paradoxical self-defeat. I argue that these readings only give it new clothing. Hacker's "traditional" reading ends up ascribing a metaphysical conspiracy

* This paper was written with the support of CNPq (Brazilian Research Council for Scientific and Technological Development). I thank IEAT (Institute of Advanced Transdiciplinary Studies - UFMG) for a period of resarch leave. Part of this paper has appeared in several talks: at University of Quebec Montreal, Universidad de Antioquia, and Trinity College Dublin. I thank all audiences for valuable feedback. I have profited also from comments of several readers, who read a longer manuscript of which the present paper is just a part: Andrew Lugg, Craig Fox, David Stern, Juliet Floyd, Max Weiss, Sebastien Gandon, and Thomas Ricketts. I thank them all. Artigo submetido em 17/05/17. Aceito em 02/08/17.

** Universidade Federal de Minas Gerais - CNPq. Belo Horizonte - MG - Brasil.

KRITERION, Belo Horizonte, nº 140, Ago./2018, p. 591-611 
to the "Tractatus", which is incompatible with the aims of the book. The "resolute" reading of Diamond and Conant ascribes an authorial conspiracy to Wittgenstein, which contradicts his views on authorship and method. Grounded in the difficulties found in both sides of the current debate, I conclude this paper by proposing several requirements that the correct interpretation of the "Tractatus" should fulfill.

Keywords Wittgenstein, "Tractatus", resolute reading, paradox, Kierkegaard.

Es ist himmelschreiender Unsinn, aber an welchen Unsinn gewöhnt sich denn nicht das menschliche Ohr? (Kürnberger)

\section{Introduction ${ }^{1}$}

One must, Wittgenstein claims, "throw away the ladder after he has climbed up it" (TLP 6.54). Anyone who understands him must overcome (überwinden) his sentences and recognize them as nonsense after they are used. ${ }^{2}$ However, how can he make such claims? It seems that the very sentences of the book explain (or give the argument for) why they are nonsense. As such, presumably, they should be true. However, nonsense, one must think, cannot be true and explain or justify anything. Thus, the book seems paradoxically self-defeating: if its sentences are true, they must be nonsense, but if they are nonsense, they cannot be true. ${ }^{3}$

In this paper, I discuss the problem by taking as a point of departure the debate between "resolute" and "traditional" interpreters. I address the issue sideways, as it were, with a critical examination of both sides. ${ }^{4}$ So I accept the current division between the "traditional" and the "resolute" reading -

1 I will use the following abbreviations: TLP or "Tractatus" for "Tractatus Logico-philosophicus"; NB for "Notebooks"; MDMN for "Notes Dictated to Moore in Norway"; WLC30-2 for "Wittgenstein's Lectures Cambridge 1930-32"; SRLF for "Some Remarks on Logical Form"; WPPO for "Ludwig Wittgenstein: Public and Private Occasions"; PR for "Philosophical Remarks"; WVC for "Wittgenstein and the Vienna Circle"; MS for "manuscriptfrom the Nachlass".

2 I follow Goldfarb's suggestion and translate 'überwinden' as 'overcome' (Goldfarb, 2011).

3 The first conditional is formulated in Morris \& Dodd (2009); the second is derived from the works of Diamond, who argued that nonsensical sentences can neither show something, nor be true in a peculiar way.

4 I address the issue head-on in Engelmann (forthcoming). 
although, arguably, it is neither precise nor sufficiently comprehensive $-^{5}$, but I focus on the works of the interpreters who created the debate. In section 1, I discuss Hacker's "traditional" interpretation and show that he ascribes to the "Tractatus" a doctrine that is incompatible with aims and strategies of the book. Instead of solving the apparent paradox, Hacker's reading gives it new clothing by means of a kind of metaphysical conspiracy. In sections 2 and 3, I intend to show that Hacker's most prominent "resolute" critics, Diamond and Conant, do not fare much better when it comes to dissolving the apparent paradox. In order to show this, I distinguish two phases in their interpretation, which I name "frame-context reading" and "piecemeal reading" (the latter is an extension or adjustment of the former). In both phases, I argue, they do not solve the traditional paradox, but rather replace it by a paradoxical "authorial" conspiracy grounded in their claim that one must understand the author of the "Tractatus", and not his propositions. In section 3, I intend to show that Conant's comparison between Wittgenstein's and Kierkegaard's authorial methodology, which seems to underpin his idea of an ironical procedure or authorial "method of deception" in the "Tractatus", cannot be correct. Besides, the resolute reading does not account for the real method of the book.

Although both mainstream lines of interpretation fail to dissolve the most traditional interpretative problem of the book, their insights provide the grounds for what the correct interpretation must achieve. In section 4, the last section of this paper, I outline some requirements that the correct interpretation of the book should fulfill. ${ }^{6}$

\section{Hacker's "Metaphysical Necessities"}

According to resolute readers, Hacker is one of the major proponents of the "traditional reading of the Tractatus", for he supposedly thinks that the sentences of the book are illuminating nonsense that show inexpressible nonsensical truths. For resolute readers, this means that Hacker does not take seriously the fact that Wittgenstein urges his readers to throw away the ladder

5 Note that there is disagreement concerning the current taxonomy of the debate. The disagreement finds expression in various ways. For instance, in McGinn's third alternative (2006); in Sullivan's reading (2004); in White's (2011) critique of both resolute readers and Hacker. One might also find difficult to classify several introductions to the book with the current taxonomy: for instance, Mounce (1989), White (2006), and Nordman (2005). In fact, the very field of resolute readers, as is well known, is not uniform (on this issue, see Conant, 2007).

6 The reader will notice that Diamond and Conant get more attention than Hacker. Their reading was supposed to attack a traditional reading, but after thirty years of debate it has become itself the most "traditional" interpretation. As such, it naturally deserves more attention. 
(TLP 6.54). Although Hacker uses the expression 'illuminating nonsense', this line of criticism is not completely successful, for Hacker thinks that nonsensical propositions "show nothing about the world" (1986, p. 18). Actually, he claims that only meaningful (genuine) propositions show (1986, p. 24). For him, they show what Tractarian nonsense means to say (see 1986, p. 26). Therefore, his views are prima facie more plausible than the views sometimes attributed to him.

However, Hacker's interpretation faces other difficulties, which are connected but are not identical with the misleading slogan "illuminating nonsense shows something". Let us look at some of them. He calls the philosophy of the "Tractatus" "transcendental idealism coupled with empirical realism" (Hacker, 1986, p. 63). . For Hacker, Wittgenstein establishes the "conditions of possibility" of language by means of the picture theory of meaning (Hacker, 1999 and 1986). The essence of this theory, in Hacker's view, is that kinds of simple objects determine the combinatorial possibilities (categories) of simple names (Hacker, 1986, pp. 20-21). This is 'realism' (see 1986, p. 63). ${ }^{8}$ Supposedly, meanings are taken from simple objects and "injected" into simple names. According to Hacker, this injection is called 'projection', and it is the task of a "transcendental subject". This is 'transcendental idealism'. It is 'transcendental', for Hacker, because it can neither be an ordinary fact nor a thought that such an injection or 'projection' takes place: "it is a mental act (albeit of a transcendental self, not the self studied by psychology) that injects meaning or significance into signs, whether in thought or in language" (1986, p. 75; my emphasis). Thus, according to Hacker, meaning injection is a "transcendental" mental act that must take place before thought and language. As such, it is a non-normative relation between indefinable names and objects (1986, p. 73).

However, in the "Tractatus" nothing at all is said about mental acts of a transcendental subject. Contrary to Hacker's view, projection is normative: it is explicitly grounded in general rules (TLP 4.01n). Moreover, Hacker's interpretation is really at odds with the very aims of the "Tractatus". Nowhere Wittgenstein claimed to have invented "transcendental idealism coupled with realism". Actually, he wrote that the book provided us with nothing less than "on all essential points, the final solution of the problems" (TLP, preface; my emphasis). This means at least one thing: "All theories that say: "This is how it must be, otherwise we could not philosophize", [...], etc., etc., must of course

7 Hacker's reading is close to Malcolm (1986) - see Hacker (1999) -, and also Pears (1987).

8 In Hacker's reading the elimination of Russell's theory of types comes with the highest possible price: all types (but also kinds) are, as it were, put inside simple objects. According to him, type restrictions are unsayable, but are presupposed by Wittgenstein: knowing the meaning of a name means knowing all its combinatorial or type restrictions (Hacker, 1986, p. 21). 
disappear" (NB, 44; my emphasis). Wittgenstein also told his friend Hänsel in 1919 that the book is the "logical finishing (logische Erledigung) of philosophy" (Hänsel, 2012, p. 45). We should be able to get through with philosophy after understanding his book. In Hacker's "Tractatus", however, Wittgenstein assumes a very obscure metaphysical doctrine that implies an out-of-this-world meaning injection that depends on mental acts of a 'transcendental subject.' Of course, such a doctrine is no "final solution of the problems" or the "logical finishing of philosophy" at all, but a metaphysical theory about "how it must be", the very target of the book (see, for instance, NB, 44; TLP: 4.003, 4.112).

Hacker's interpretation also seems to eliminate one of the most fundamental insights of the "Tractatus", as shown on the first page of the "Notebooks": "logic must take care of itself" (also TLP 5.47). According to Wittgenstein, "the whole theory of things, properties, etc. is superfluous" (NB, p. 2). To assume, therefore, as does Hacker, that the "Tractatus" is committed to a kind of necessity de re (combinatorial possibilities of objects determine possibilities for names) grounded in types or kinds of objects violates the autonomy of logic that Wittgenstein considered fundamental. ${ }^{9}$ Certainly, a theory of things is not superfluous in Hacker's interpretation. However, according to Wittgenstein it is an error to talk about the meaning of signs: "in logical syntax the meaning of a sign ought never to play a role" (TLP 3.33). The problem with Russell's theory of types is not that it is "metaphysically necessary" and nonsense, but that meaning ought never to play a role in logic. One could paraphrase Wittgenstein's critique of the axiom of reducibility and apply it to Hacker's "types of things": "logic has nothing to do with the question whether our world really is like that or not" (TLP 6.1233). Hacker is simply saying that "the world must be like this and like that" and then adding that the claims are "ineffable metaphysical necessities" (1986, p. 54; see also p. 51, quoted below). Thus, it is not a good move, as it were, to put types or kinds of things into simple objects as "conditions of the possibility of representation", as Hacker does (1999, p. 120). After all, the only thing that really matters in the "Tractatus" is to "construct a system of signs with a particular number of dimensions - with a particular mathematical multiplicity" (TLP 5.475).

Because Hacker attributes a doctrine, ineffable or not, to the "Tractatus", he must accept that Wittgenstein misleads the reader of the book when he

9 The expression 'de re' occurs in Hacker (1999, p. 120) and expresses the idea of "metaphysical necessities". For Hacker, Wittgenstein's later philosophy is a critique of the alleged Tractarian idea of 'de re' necessity. In the "Philosophical Investigations", according to Hacker, contrary to the "Tractatus", Wittgenstein defends a 'de dicto' necessity. See Engelmann (2011) for a critique of the presuppositions of such a view and Engelmann (2013) for a different interpretation of Wittgenstein's philosophical development. 
says that all necessity is logical necessity in 6.37 , for, supposedly, there is also metaphysical necessity:

First, it is misleading of the Tractatus to say that all necessity is logical necessity, since after all most of the propositions of the Tractatus itself seem to state non-contingent truths, metaphysical necessities about the nature and the essence of reality, of any possible world (1986, p. 51; my emphasis).

Note that Hacker, some pages later, makes the same point quite categorically: "Wittgenstein did think, when he wrote the "Tractatus", that there were ineffable metaphysical necessities" (1986, p. 54). Supposedly, "ineffable metaphysical necessities" are "the metaphysical doctrines of the Tractatus" (1986, p. 80). Indeed, if Wittgenstein in the "Tractatus" accepts that there is only logical necessity, logical necessity has to be presented in a logical symbolism (and its specific notations such as truth tables), and in this case the remark in 6.37 is rather trivial. However, if he assumes, as Hacker claims, "metaphysical necessities" or "doctrines" presented in "non-contingent truths" - nonsensical or not, explicitly stated or not-, Wittgenstein indeed misleads the reader. For in this case the "Tractatus" supposes that we must accept ineffable metaphysical (philosophical) doctrines in order to criticize other metaphysical (philosophical) doctrines. This looks like a strange metaphysical conspiracy, for "metaphysical doctrines" could not lead Wittgenstein to the logische Erledigung of philosophy. He would not be able to make "all theories that say 'This is how it must be' disappear" (NB, 44), since his own metaphysical theory would survive. This would mean that he was just reheating speculative metaphysics in the guise of ineffable metaphysics. Therefore, Hacker's reading implies a colossal failure for the "Tractatus" from the outset, and thus aggravates the apparent paradoxical self-defeat.

\section{Diamond and Conant: Resoluteness}

The most important lesson of the resolute reading concerning the "Tractatus" is that one must find a way to avoid Hacker's metaphysical conspiracy. The guiding insight of the reading, with which I agree, is that the purpose of the "Tractatus" is to stop metaphysics, and not to reheat it in the form of ineffable doctrines. ${ }^{10}$ However, as we will see, the resolute reading ends up creating its own kind of conscious conspiracy. Diamond and Conant have defended what 
one might think are two somewhat different versions of their interpretation in the last three decades. ${ }^{11}$ The first I will call 'frame-context reading' and the second, which apparently makes the first more precise, 'piecemeal nonsense reading'. The frame-context reading, as Diamond and Conant argue, is grounded in the idea that we must take the 'frame' of the book seriously, namely, the preface and the 'conclusion,' where Wittgenstein says that his propositions are einfach Unsinn and say that we should understand him (TLP: preface and 6.54, respectively). They think that "to understand him" means "to understand him, the author, instead of his nonsensical sentences" (Diamond, 1996, p. 19). ${ }^{12}$ In section 3, I discuss their idea of "understanding the author". First, let us look at the "frame" idea. The "frame" of the book, Conant argues, gives us the author's "directions to read the book" (1993, p. 216). According to Conant and Diamond, the frame instructs us that there is only one kind of nonsense: nonsense is simply nonsense. So the nonsense of the book is simply nonsense as well, and not deep nonsense of the "metaphysically necessary" kind, as Hacker claimed. Nevertheless, how can we follow the remarks of the book, according to Diamond, if they are simply nonsense? We supposedly 'imaginatively' follow the nonsensical sentences of the "Tractatus" as "transitional remarks" in order to discover that they are, indeed, simply nonsense (Diamond, 1991). Thus, the resolute reading avoids the attribution of a metaphysical conspiracy to the "Tractatus", as long as we follow the instructions of at least some sentences of the book.

However, more than the 'frame' is involved in their argument, for the idea that there is only one kind of nonsense depends on Diamond's reading of the context principle (TLP 3.3) and aphorism 5.4733. ${ }^{13}$ Traditional readers such as Hacker, Diamond correctly argues, rely on the idea that the sentences of the "Tractatus" are nonsense because they violate combinatorial possibilities of simple objects (requirements of the inexpressible picture theory of meaning). For Diamond (1996), so it seems, the context principle teaches us that this is not the Tractarian view of nonsense. In order to see whether words have meanings, we have to determine the contribution that they make to the sense of the proposition (TLP 3.3). Thus, if something that is supposedly a proposition is in fact nonsense,

spirit') of the later Wittgenstein. Her major point is that one cannot correctly read the later Wittgenstein, if one attributes a series of philosophical-metaphysical doctrines to the early work.

11 I will deal primarily with the Diamond-Conant resolute interpretation, because the details and bifurcations of the resolute reading are difficult to unify, but I must suppose that they are grounded in Diamond's work.

12 See also Conant (1990, 1993, 1995 and 2000).

13 Ishiguro (2006), McGuinness (2005), and Winch (1969 and 1987) used the context principle in order to avoid the attribution of realism to the "Tractatus" by claiming that the meaning of a name is identical with its logical syntactical employment (simple objects do not give the essence of meaning; contextual use does). Diamond goes further and uses it to disqualify what she takes to be the traditional view of Tractarian nonsense as something that shows inexpressible truths (Diamond, 1996, pp. 109, 194-196). 
it has no sense; its constituent parts, therefore, have no meaning at all. They do not have meaning simply because we have failed to give them meaning, and not because signs express an impossible combination of names or objects (TLP 5.473n). According to Diamond and Conant, therefore, the gibberish "Wigle Pigle Digle" is as nonsensical as "The world is the totality of facts". In both cases, supposedly, we could have given meaning to the signs, but have failed to do so (I come back to this point below). So it seems that aphorisms 3.3 and 5.473 deliver a way to determine the nonsensicality of sentences.

It has been noticed that there is a problem with Diamond and Conant's 'frame' strategy; they use sentences of the 'body' of the book as part of the frame (see, for instance, Proops, 2001). Conant's answer to this worry is that remarks outside the "frame" (introduction and "conclusion") might function as frame elucidations according to their "role within the work" (2000, p. 100). ${ }^{14}$ This gives us a broad sense of 'frame'. The problem with Conant's adjustment of the frame, however, is that one might well say now that he does not "take seriously" enough the very story of the frame. Moreover, the adjustment suggests exceptions that Wittgenstein does not seem to allow. Wittgenstein says in the "frame" (in the restricted and broad senses given to the word by resolute readers) that his propositions, and not some of them, elucidate in the same way and that they are all nonsense (T: 4.112, 6.54). The very context principle, for instance, is one of the sentences that "cannot be said" (see PR §12). Besides, the assumption that propositions $6.53,6.54$, and 7 are the conclusion-frame or ending of the "Tractatus" is far from obvious. One must observe that Wittgenstein never identifies the conclusion or ending with the final three aphorisms of the book. ${ }^{15}$ According to the numbering system of the "Tractatus" itself, explained in the only footnote of the book, this cannot be completely correct. Strictly speaking, the 'conclusion' or the 'ending' is aphorism 7. Aphorisms 6.53-4 explain or clarify 6.5 , which in turn elucidates the role of 6 . Accordingly, if we speak of "conclusion" or "ending" of the book, we must take into account how 6 leads to the outcome of the book, namely the silence required (TLP 7). Thus, the very resolute idea of the "conclusion" or "ending" as part of the frame is dubious.

14 See also Conant and Diamond (2004), where they claim that the reader must recognize the function of the frame remarks.

15 Presumably, the significance of the 'frame' can be seen in an undated letter that Wittgenstein wrote to friend and publisher of "Der Brenner" Ludwig von Ficker, in which he urges him to look at the preface and the ending of the book, where the sense of the whole is easier to understand. In this letter, however, Wittgenstein does not specify aphorisms $6.53,6.54$, and 7 as the ending. In another letter to von Ficker Wittgenstein claims that the numbering of the book must be printed because without it the book would be an "incomprehensible jumble" (letter from 05.12.1919). I presume that this letter is as important as the undated one. 
Another dubious matter concerning the resolute reading is the status of the logical symbolism of the "Tractatus". ${ }^{16}$ Diamond argues in her early work that Wittgenstein's goal is "to describe a way of writing sentences, a way of translating ordinary sentences into a completely perspicuous form" (1996, p. 184). ${ }^{17}$ Nonsense cannot be written in the symbolism when it is supposedly analyzed and so the symbolism might be understood as a criterion of sense. Thus, for resolute readers, the symbolism seems to show that someone has failed to give meaning to signs. But if so, one cannot be sure why Wittgenstein would be authorized in using it, if it is not part of the "frame" - even if understood in its broad sense. This gives us a reason for why the later Conant writes that notations are merely "put forward as proposals" (Conant, 2007, p. 47). So, if we wish, we might try to use the notations to get rid of nonsense. However, we still do not know why we are able to do this without paradox, for there are notational devices in several parts of the book, and Wittgenstein clearly connects his symbolism with the functional understanding of a sentence (TLP 3.318). Moreover, the story about "proposals" does not agree with what Wittgenstein writes about the logical symbolism. The general form of propositions, the central notational device of the book, is not taken to be an optional proposal. It is nothing less than the very "essence of proposition" (TLP 5.471; Ogden's translation). It is "a description of any sign-language whatsoever" (TLP 4.5; Wittgenstein's emphasis). Of course, one should take Wittgenstein seriously here. Otherwise, everything he writes might be deceptive (I will deal with 'irony' and 'deception' in section 3).

The idea that notations are proposals defended by the later Conant, however, is just a part of a radical solution to the problematic status of a "general approach" to nonsense and the analysis of particular cases inside the resolute reading. The idea is an aspect of the "piecemeal nonsense reading" (this is phase two of the resolute reading). According to the later Conant and Diamond (2004), there is no general criterion of sense at all in the "Tractatus": neither the logical symbolism, nor bipolarity, nor the context principle can be a general criterion of sense. ${ }^{18}$ Supposedly, only a case-by-case study of sentences can make nonsense

16 Something similar could be said of McGinn's alternative reading (1999) and (2006). McGinn's major purpose is to make clear that the "Tractatus" is not purely negative in its goals and that important insights concerning logic are conveyed in the book. So she thinks that some sentences of the "Tractatus" elucidate and others don't. The elucidative ones are those connected to logic. However, it is not clear why we should accept the distinction elucidative and non-elucidative sentences, nor why and how the ones about logic are elucidative. Moreover, it just seems that the whole book is about logic.

17 Sometimes it seems that also the notion of 'bipolarity' plays an important role in Diamond's reading (1996, pp. 195-201). See also Goldfarb (1997, p. 68). However, Diamond (2004) denies it.

18 See, however, Kuusela (2011) for a resolute reader that relies on the notation. 
manifest. This shift or, perhaps, adjustment of the reading, is a response to Goldfarb (1997), who argued that a resolute understanding of Tractarian analysis without the assumption of a general approach to nonsense was lacking in the reading. Goldfarb suggested the "case-by-case approach" (1997, p. 71). Thereafter, Diamond has argued that a piecemeal view of nonsense is needed because "any propositional sign can be used in various ways" (Diamond, 2004, p. 203; see also footnote 65). Presumably, the point of a piecemeal approach is that signs in sentences can be analyzed by means of a theory-free procedure. Conant and Diamond (2004) think that according to the "Tractatus" one cannot rely on a general method, but must take into account how signs and projections are actually meant by philosophers in each case before declaring a sentence nonsense. Supposedly, one can show that each particular sentence is nonsense only if one cannot make sense of it. Therefore, a careful examination of what a philosopher might mean should show that nothing is meant or projected with a nonsensical string of words. This should be the case with the sentences of the book as well (Diamond, 2004; Conant and Diamond, 2004).

With the piecemeal view of nonsense, I think, resolute readers simply aggravate the problem of analysis in their reading, instead of solving it, for they do not account for real Tractarian analysis. One must note here that if Wittgenstein really defended a piecemeal conception of nonsense in the "Tractatus", it would be somehow connected with his idea of analysis: a process of interpretation and definition grounded in Russellian analysis that ends with logically independent elementary propositions and simples. However, the ideas of 'logically independent elementary propositions' and 'simples' never appear in any "piecemeal" analysis of resolute readers.

This point is quite relevant, for Wittgenstein criticizes and abandons his idea of analysis in the "Tractatus" when he returns to philosophy in 1929 (see SRLF). Thus, he must have thought that the idea was important at the time he wrote his first book. So Hacker (2000) is right when he points out that resolute readers do not deal with the fact that Wittgenstein changed his philosophy and criticized the mistakes of the "Tractatus" later. Conant has only a general answer to this. Initially he thinks that the most relevant change after the "Tractatus" is a change of method (Conant, 1995); some years later, he claims that the change is the change from one to several methods (Conant, 2007 and 2011). However, both answers are problematic for two reasons. First, because the "method" of the "Tractatus" is not the method that Conant attributes to it (I come back to this below). Second, they miss the point of the objection. Wittgenstein came back to Cambridge, as he said to Schlick, to study the visual field (see WVC, p. 17). The study of the visual field is an investigation of visual space and color, two 
central notions that are expressed in "statements of degree", whose analysis seems to be incompatible with the "Tractatus" (see SRLF). All those nonmethodological issues appear in Wittgenstein's project of a phenomenological language (see SRLF) ${ }^{19}$ Conant and Diamond do not account for those facts.

In addition, with the piecemeal view of nonsense resolute readers willingly put themselves in a position similar to Lewis Carroll's Alice trying to disentangle what Humpty Dumpty might mean with his nonsense. Humpty Dumpty claims that he can mean whatever he wants with words and that other people have to try hard to find out what he means:

[...] "There is glory for you!". "I don't know what you mean by 'glory'," Alice said. Humpty Dumpty smiled contemptuously. "Of course you don't - till I tell you. I meant 'there's a nice knockdown argument for you."' "But 'glory' doesn't mean 'a nice knockdown argument'," Alice objected. "When I use a word", Humpty Dumpty said in a rather scornful tone, "it means just what I choose it to mean - neither more nor less. ("Through the Looking Glass", p. 229).

In the "Tractatus" or notebooks, however, Wittgenstein does not adopt Alice's patient piecemeal strategy: in no place he disentangles his own nonsensical propositions or tries hard to find out how other philosophers really mean their sentences. There is no concern in the "Tractatus" with "ways of making sense", contrary to what Conant assumes (2002, p. 419). Certainly, the readers do not need to discover the nonsensicality of the sentences of the book case-by-case, for the author tells us explicitly that they are nonsense (TLP 6.54). We do not have to discover in a piecemeal way the nonsensicality of each philosophical sentence enunciated by a philosopher either, for Wittgenstein also tells us that they are nonsensical. In fact, he says why they are nonsensical, namely, because the very philosophical questioning rests on the misunderstanding of the "logic of our language"; philosophical sentences do not respect the limits of language (TLP: preface, $4.003,4.11 \mathrm{n}, 6.53$ ). It would be quite extraordinary not to tell his readers that one can only understand that his propositions are nonsense if one looks at each particular one and tries to make sense of it. ${ }^{20}$ One must conclude that this means that the resolute kind of piecemeal analysis is not needed. Presumably, if he suggests in the "frame" that philosophical questioning rests

19 On the phenomenological language see Engelmann (2013), (2017), and (2018).

20 As far as I can see, there is also no kind of dialogue (or dialectic) between Wittgenstein and a philosopher trying to project signs. For a dialectical approach of the "Tractatus" see Ostrow (2002). I am not sure if such an approach is committed to the idea of an 'interlocutor' in the "Tractatus", but without one the sense of 'dialectical' is unclear to me. 
on "misunderstandings of the logic of our language", the understanding of the logic of our language alone should make the point.

In fact, even later in the middle period, when Wittgenstein indeed introduced a kind of "piecemeal view of nonsense" (a case-by-case procedure), he was not concerned, at least in a first moment, with the details of "philosophical projections". In a lecture in 1930, Wittgenstein exemplifies nonsense with the first lines of Jabberwocky: " "Twas brillig and the slithy toves..." (WLC3032 , p. 3). However, he does not go on and say something like "let's see how those words are projected" or "let's see how they are meant", although it is obvious that Humpty Dumpty "translates" the nonsense into ordinary language. 'Brillig', for instance, means "four o'clock in the afternoon - the time when you begin broiling things for dinner" ("Through the Looking Glass", p. 232). Wittgenstein does not say, "if the words are meant in this way, they make sense; if they are meant in that way, nonsense". Instead of trying to carefully look at how words might be meant, in a clear case in which such a procedure was at hand, Wittgenstein simply says about "Twas brillig...": "This can be analyzed into subject and predicate, but is nonsense" (WLC30-32, p. 3).

Trying to make sense of nonsense is not the relevant issue in the "Tractatus". The reason why it is not is displayed in Moore's notes of one of Wittgenstein's lectures in 1933: "when he [Wittgenstein] said 'That means nothing' or 'Nonsense' what he meant was 'With the common method of projection it means nothing,", (Moore, 1966, p. 260). Thus, extraordinary projection methods are irrelevant to Wittgenstein. This is also the case, at least at a first moment, when he later presumably adopts a piecemeal view of nonsense.

Arguably, Diamond and Conant offer us important insights about how to read Wittgenstein's later work. However, they project the later work into the "Tractatus" without accounting for Wittgenstein's long struggle in the middle period. "The piecemeal view of nonsense", the idea of "ways of making sense", and the "mirror metaphor" (Conant, 1995, p. 249) are all views developed in Wittgenstein's middle period and they characterize his later philosophy (see Engelmann, 2013).

Instead of assuming a "piecemeal view of nonsense, one should think that the "Tractatus" presupposes that we, speakers, have attached meaning to the signs in our language, i.e., that we "have made an arbitrary determination" (TLP 5.473). Arbitrary determinations are already in place in ordinary language because general rules have been used to determine meaning (TLP 4.014). Even though correlations of signs and meanings that we, speakers, have made are indeed determined arbitrarily, we are all committed to them. It is because we are committed to arbitrarily determined rules that 'identical' is not a property 
and that "Socrates is identical" is nonsense (TLP 5.4733). Indeed, 'identical' does not mean a property according to the common method of projection. Of course, there could be a rule in our language according to which 'identical' meant something different, for the rule and the symbol are arbitrary (MDMN, p. 114). However, the arbitrary rule of symbolization of our language is not that one. If Humpty Dumpty says that "Socrates is identical" means "Socrates is wise" is irrelevant, because our arbitrary rules of projection are already in place. Therefore, we can dispense with the talk about "trying to make sense" and "ways of making sense" in the "Tractatus": our arbitrary rules are already in use.

\section{On "Understanding the Author" and His Method}

One of the most worrisome features of both versions of the resolute reading is that they must suppose that Wittgenstein misleads the reader. We have seen above that a similar supposition operates also in Hacker's interpretation. However, for resolute readers the "strategy of deception" is conscious and expresses a supposedly ironical procedure or authorial 'method'. According to the resolute reading, "understanding the author" means understanding that Wittgenstein wants to deceive us into thinking that he is offering us mock metaphysical doctrines with the sole purpose of bringing us to see that they are simply nonsense. Such a view on "understanding the author" of the "Tractatus" is defended more emphatically in Conant's work, but Diamond explicitly agrees with Conant's strategy - Diamond (1996, pp. 18, 198); Conant and Diamond (2004, p. 82). Conant claims that the real method of the "Tractatus" is similar to Kierkegaard's method, which he supposedly employs in, for instance, the "Concluding Unscientific Postscript" and makes explicit in "The Point of View of My Work as an Author". Wittgenstein and Kierkegaard, according to Conant, deceive the reader with a "mock doctrine" that appears to make sense (Conant, 1995, p. 286). In Kierkegaardian terms, the 'method' would consist in "apparently offering" metaphysical claims to the reader of the "Tractatus" in order to make him realize that "nothing of the original form" was given to him (Conant, 1989, p. 262). Such a procedure characterizes a "strategy of deception" combined with an "incessant activity of irony" (Conant, 1993, p. 215). Supposedly, by following some hints of the author we should either throw away Wittgenstein's "mock doctrine" step-by-step (piecemeal view), or at the end of the book when we supposedly fully understand Wittgenstein's trick or strategy of deception (frame view).

Perhaps Conant is right about Kierkegaard's method. Indeed, evidence (below) suggests that he correctly describes at least one of its features, according 
to Wittgenstein. However, the parallel with the method of Wittgenstein's "Tractatus" is incorrect.

Of course, it is plausible to think that Wittgenstein grasped Kierkegaard's "strategy of deception" at the time he wrote the "Tractatus", that he liked it, and that he employed it. Although Conant does not provide direct evidence for his interpretation, one could try to show, in principle, that Wittgenstein read Kierkegaard before finishing the book or that he might have been aware of Kierkegaard's strategy through, for instance, Theodor Haecker. ${ }^{21}$ However plausible the idea might be, there is no evidence for it. There is no reference at all to Kierkegaard in the "Tractatus" or in the "Notebooks". Moreover, Kierkegaard is never the subject of conversations with Paul Engelmann, who was arguably Wittgenstein's most important interlocutor during the First World War, when he wrote the "Tractatus". ${ }^{22}$ The first references to Kierkegaard appear in conversations from 1919 with Hänsel (2012, pp. 45, 54), and some months later with Russell (2002, p. 334), i.e., a year or so after Wittgenstein had finished the "Tractatus". Nothing in these conversations suggests the use or even awareness of Kierkegaard's "strategy of deception".

Still, one could argue that there is a coincidence of strategies. Wittgenstein could have employed the strategy in a secret way when he wrote the "Tractatus". Fortunately, there is direct evidence that he was aware of Kierkegaard's strategy of deception years later. However, as we will see, it is precisely the fact that Wittgenstein was aware of it that shows that he did not employ it in the "Tractatus". In 1931, Wittgenstein refers to both, Kierkegaard's irony and his strategy of deception. His irony is seen as something bad: "Dealing with authors like [...] Kierkegaard makes their editors presumptuous. [...]It is probably that the irony of an author inclines the reader to become presumptuous" (MS 183, p. 68; WPPO, p. 77; Wittgenstein's emphasis). Presumption, however, is not the only sin that irony might generate. Wittgenstein not only sees Kierkegaard's use of irony, but he is also quite aware of why Kierkegaard uses it. He makes clear Kierkegaard's strategy of deception in the following way:

Kierkegaard's writings have something teasing (etwas Neckendes) in them and this is, naturally, intended [...] And I know quite well that with his mastery of it Kierkegaard reduces the aesthetic to absurdity $\&$ that of course he wants to do that [...] (WPPO, p. 131; MS 183, p. 122; slightly modified translation of the first sentence)

21 Haecker helped to disseminate Kierkegaard's works through "Der Brenner", and ended up receiving Wittgenstein's financial help through von Ficker (McGuinness, 1988, p. 207). Haecker explicitly discusses Kierkegaard's strategy in quite general terms (see, for instance, 1913, p. 66).

22 See Paul Engelmann (1968). 
"The aesthetic" and its speculations are introduced in Kierkegaard's works by means of pseudonyms, for instance, Victor Eremita in "Either/Or", who is the editor of letters of $A$ and $B$, Johannes de Silentio in "Fear and Trembling" and Johannes Climacus (who is supposedly getting rid of the aesthetic-speculative view) in the "Concluding Unscientific Postscript to the Philosophical Crumbs". Pseudonymous works contrast to Kierkegaard's own works and preaching: the religious works (see, for instance, Kierkegaard's "For Self-examination"). In "Point of View for my Work as an Author", Kierkegaard points out that the goal of his work as a whole is "religious". Supposedly, he begins where the reader is, i.e., in an aesthetic point of view, in order to bring "the aesthetic to absurdity", as Wittgenstein claims. As a result, the reader might accept a religious point of view, i.e., do Christian things. It is plausible to think that Kierkegaard achieves his dialectical goal by means of doctrines ("mock doctrines", as Conant says) incapable of solving the "paradoxes" of Christian faith. In any case, Kierkegaard's trick consists in dialectically engaging with the aesthetic point of view in order to make the reader "transcend" it after its "absurdity" is shown. So far, so good: the passage above shows that Wittgenstein was aware of Kierkegaard's 'method' or 'strategy of deception'. However, in the next paragraph of the same passage Wittgenstein makes clear that he would not employ it:

\footnotetext{
The idea that someone employs a trick in order to get me to do something is unpleasant. It is certain that in order to do this (in order to employ this trick) one needs a lot of courage and [it is certain] that I would not have this courage - not even remotely (nicht im entferntesten). But the question is whether it would be good|correct to employ it [the trick], if I had this courage. I believe that besides courage, it would require lack of love for the neighbor (Mangel an Liebe zum Naechsten) (MS 183, pp. 122-3; WPPO, p. 131; slightly modified translation).
}

The unpleasantness that Kierkegaard's "method" generates is the least of the problems for a resolute interpretation here. What is fundamental is that Wittgenstein confesses that he would not even remotely have the courage to employ Kierkegaard's trick of deception. If it is certain that he would not even remotely have the courage to do it, he certainly did not do it in the "Tractatus". Note that he wrote the remarks above years after finishing the "Tractatus". Therefore, there is no question of a change of mind concerning a secret use of the "method of deception". Moreover, he suggests that it would not be correct to use Kierkegaard's trick - moral (or religious) reasons, which Kierkegaard himself should accept, would prevent him from doing it. For Wittgenstein, Kierkegaard's trick, namely, bringing the reader to the "right view" by means of deception is a trick that he would never use. Thus, there is no ground to suppose that Wittgenstein employed it in the "Tractatus". The fact that he 
admired Kierkegaard does not make him a "mystic of the paradox", a view against which Conant forcefully argues, but it does not make him a user of a Kierkegaardian method grounded in deception either.

However, it is not just Wittgenstein's remarks on Kierkegaard's trick that are at odds with a deceiving strategy or "method". In fact, there is no sentence in the frame, or in the body of the "Tractatus" that really supports the idea of an ironical procedure - even less so outside the book, as we have just seen. Moreover, the very idea of a method grounded in deception and irony is at odds with the real method of the "Tractatus". The expression ' $\boldsymbol{m y}$ method' appears only once in the book (TLP 4.1121). ${ }^{23}$ 'My method' is not to be confused with what "the correct method in philosophy would really be" (TLP 6.53; my emphasis). Evidently, Wittgenstein neither says "propositions of natural science", nor waits for someone to say something metaphysical in the book, as prescribed by the would-be method in 6.53 . Note that he does not claim that the method in 6.53 is his method. The method prescribed in 6.53 is a result of the book, and not the method that he employs there. Therefore, "my method" for Wittgenstein simply means what he says that it means, namely, "my study of sign-language" (TLP 4.1121). ${ }^{24}$ This is indeed the method of the "Tractatus", where a study of 'proposition', 'language', and 'logic' is presented by means of a new symbolism. ${ }^{25}$ There is nothing ironical or deceptive in his method.

There is also something profoundly puzzling about the very attribution of an ironical-authorial method to the "Tractatus". ${ }^{26}$ When someone says something ironical, we do not take this person at his word. However, resolute readers usually point out that traditional readers do not take Wittgenstein seriously. Besides, if resolute readers allow themselves to interpret the "Tractatus" as

23 Oddly enough, Conant counts TLP 4.112 as part of the frame (see Conant, 2000 and Conant and Diamond, 2004). One would think, thus, that 4.1121 , which helps elucidating 4.112 , would also be part of the frame. 4.1121, however, leaves no doubt concerning the real method of the book.

24 An interesting issue concerning the resolute interpretation is the status of the method presented in 6.53. The early Diamond and Conant defended that 6.53 was not the method of the "Tractatus", but the would be method of philosophy (see Conant, 1995). This does not seem to be compatible with the 'piecemeal' reading, since 6.53 suggests a case-by-case procedure - see Goldfarb (1997), Kremer (2007). For the later Diamond (2004) and Conant (2007), it seems, 6.53 might express the method used in the "Tractatus" after all. The issue is not clear.

25 In his notebooks, Wittgenstein says: "My method is not to sunder the hard from the soft, but to see the hardness of the soft" (NB, 44). In this passage and TLP 4.1121 he has the same method in mind. See Engelmann (forthcoming).

26 Goldfarb, who is often called a resolute reader, says that resolute readers assume a kind of "esotericism": "the notion that the apparent claims of the author mask a deeper authorial purpose, which, once understood, changes or even reverses the point of those claims; and that only a class of cognoscenti will come to see this deeper purpose" (2011, p. 16). This fact, Goldfarb writes, makes him a "little uncomfortable" with the reading. This, I think, is a euphemism. When all is said and done, resolute readers replace Hacker's more or less unconscious metaphysical conspiracy with a conscious authorial conspiracy. 
ironical, they must allow traditional readers to do the same. But what if one, for instance, reads 6.54 itself as a kind of ironical remark? After all, Wittgenstein could ironically deceive resolute readers into thinking that his "metaphysically necessary" propositions, as Hacker calls them, are mere nonsense. It is clear that here we have lost the ground to interpreting the book. Everything goes, for any reader can claim that a remark is ironical. The new paradox would be that each reader could take any sentence of the book as ironical or deceptive and choose an interpretation. ${ }^{27}$

\section{Some Requirements}

At this point in the history of Wittgenstein-Studies, we are interpreting interpretations of the "Tractatus" instead of dealing with the book itself. In order to change this state of affairs, however, it is quite important to look at the difficulties present in contemporary (but also in old) debates as signposts for any future reading. With this in mind, I present some requirements for the understanding of the book.

First, the correct interpretation of the "Tractatus" must explain how and why the book is not "self-defeating" or "paradoxical" without assuming any conspiracy (metaphysical, authorial, etc.). Second, we must explain why Wittgenstein claimed to have solved in essentials all philosophical problems; i.e., we must explain how and to what extent the "Tractatus" could indeed stop metaphysics. Such requirements concern primarily resolute readers and the antimetaphysical (or anti-realist) interpretations of, for instance, Ishiguro (2006), Winch (1969, 1987), Rhees (1996), Lugg (2003), McGinn (2006, 2009), and Kuusela (2011). Following Conant and Diamond (2004), one could say that, essentially, the correct interpretation should not attribute a theory of meaning and ineffable truths to the "Tractatus". It is important to notice that these essential features do not imply a resolute reading, since there is no direct commitment to the following assumptions: the frame story, the attribution of a deceiving or ironical "method to the "Tractatus", and the piecemeal view of nonsense. So, the requirements above cannot be called 'resolute requirements', but they preserve the motivating force of the resolute reading and, simultaneously, of anti-metaphysical or anti-realist readings.

Third, we must explain how the imperative of silence presented in the last sentence of the book relates to aphorism 6 and the group 6.n, which obviously solipsism"). Williams could say, of course, that the dissolution of metaphysics is meant ironically. 
drive us to the "conclusion" (or better: result) of the book in 7 . Fourth, one must explain the role of each group of sentences and how they indeed build a ladder. This is especially relevant concerning groups of sentences 1.n and 2.n, where the so-called 'ontology' of the "Tractatus" is presented. Fifth, we must account for Wittgenstein's changes in his middle period and their relation with what Wittgenstein saw in 1929 as mistakes of the book, as Hacker urged (2000). The three last requirements agree with what a 'traditional' reader asks for. ${ }^{28}$

\section{References}

CONANT, J. "Throwing Away the Top of the Ladder". The Yale Review, Vol. 79, Nr. 3: pp. 328-364, 1990.

."Must We Show What We Cannot Say?". (pp. 242-283). In: R. Flaming, M. Payne (eds.). The Senses of Stanley Cavell. Lewisburg: Blackwell University Press, 1989.

. "Kierkegaard, Wittgenstein and Nonsense". (pp. 195-224). In: T. Cohen, P. Guyer, H. Putnam (eds.). Pursuits or Reason: Essays in Honour of Stanley Cavell. Lubock, Texas: Texas University Press, 1993.

"Putting Two and Two Together: Kierkegaard, Wittgenstein and the Point of View for Their Works as Authors". (pp. 248-331). In: T. Tessin, M. Von der Ruhr, M. (eds.). Philosophy and the Grammar of Religious Belief. New York: St. Martin's Press, 1995.

"Elucidation and Nonsense in Frege and Early Wittgenstein". (pp. 174-217). In: A. Crary, R. Read (eds.). The New Wittgenstein. London: Routledge, 2000.

"The Method of the Tractatus". (pp. 374-462). In: E. H. Reck (ed.). From

Frege to Wittgenstein. Oxford: Oxford University Press, 2002.

"Mild Mono-Wittgensteinianism". (pp. 31-142). In: A. Crary (ed.). Wittgenstein and the Moral Life: Essays in Honor of Cora Diamond. Cambridge, MA: MIT Press, 2007.

. "Wittgestein's Methods". In: O. Kuusela, M. McGinn (eds.). The Oxford Handbook of Wittgenstein, Oxford: Oxford University Press, 2011.

CONANT, J., DIAMOND, C. "On reading the Tractatus resolutely: reply to Meredith Williams and Peter Sullivan". (pp. 42-97). In: M. Koelbel, B. Weiss, B. (eds.) Wittgenstein's Lasting Significance. London: Routledge, 2004.

DIAMOND, C. "The Realistic Spirit: Wittgenstein, Philosophy and the Mind". Cambridge, Massashussets: The MIT Press, 1996.

"Ethics, Imagination and the Method of Wittgenstein's Tractatus". (pp. 5590). In: R. Heinrich, H. Vetter (eds.). Bilder der Philosophie.Vienna: Oldenbourg;, 1991. 
. "Criss-Cross Philosophy". In E. Ammereller, E. Fisher (eds.). Wittgenstein at Work: Method in the Philosophical Investigations. London: Routledge, 2004.

ENGELMANN, M. L. "Instructions for Climbing the Ladder (The Minimalism of the Tractatus)". In: Philosophical Investigations. (Forthcoming).

"What Does a Phenomenological Language Do? (Revisiting Some Remarks on Logical Form in its Context)". (pp. 95-126). In: M. Silva. Colors in Wittgenstein's Philosophical Development. Palgrave Macmillan, 2017.

. "Phenomenology in Grammar: Explicitation-verificationism, Arbitrariness, and the Vienna Circle". (pp. 22-46). In: O. Kuusela, M. Ometita, and T. Uçan (eds.) Wittgenstein and Phenomenology. New York: Routledge, 2018.

"Wittgenstein's Philosophical Development: Phenomenology, Grammar, Method, and the Anthropological View". Basingstoke: Palgrave Macmillan, 2013.

. "What Wittgenstein's 'Grammar' Is Not (On Garver, Baker and Hacker, and Hacker on Wittgenstein on 'Grammar')". (pp. 71-102). In: Wittgenstein-Studien 2. De Gruyter, 2011.

ENGELMANN, P. "Letters from Ludwig Wittgenstein with a Memoir". New York: Horizon Press, 1968.

GOLDFARB, W. "Metaphysics and Nonsense: On Cora Diamond's The Realistic Spirit". Journal of Philosophical Research, Vol. XXII, pp. 57-73, 1997.

"Das Ueberwinden: Anti-Metaphysical Readings of the Tractatus". (pp. 6-21). In: R. Read, M. A. Lavery (eds.). Beyond the Tractatus Wars: The New Wittgenstein Debate. New York: Routledge, 2011.

HACKER, P. M. S. "Insight and Illusion”. 2a. ed. Bristol: Thoemes Press, 1986.

"Naming, Thinking and Meaning in the Tractatus". Philosophical Investigations, pp. 119-135, 1999.

. "Was He Trying to Whistle it?”. (pp. 353-388). In: A. Crary, R. Read (eds.).

The New Wittgenstein. London: Routledge, 2000.

HAECKER, T. "Soeren Kierkegaard und die Philosphie der Innerlichkeit". Munich: Verlag von J. F. Schreiber, 1913.

HÄNSEL, L. "Begegnungen mit Wittgenstein - Ludwig Haensels Tagebuecher 19181919 und 1921-1922”. Ed. I. Somavilla. Wien: Haymon Verlag, 2012.

ISHIGURO, H. "Use and Reference of Names". (pp. 20-50). In: P. Winch (ed.). Studies in the Philosophy of Wittgenstein. London: Routledge, 2006.

KIERKEGAARD, S. "Fear and Trembling and The Sickness Unto Death". Transl. W. Lowrie. Princeton: Princeton University Press, 1973.

. "Either/Or". Transl. H. V. Hong and E. H. Hong. Princeton: Princeton University Press, 1987.

. "Concluding Unscientific Postscript to the Philosophical Crumbs". Transl. A.

Hannay. Cambridge: Cambridge University Press, 2009a.

. "The Point of View for my Work as an Author". Transl. H. V. Hong and E. H.

Hong. Princeton: Princeton University Press, 2009b.

. "For Self-Examination and Judge for Yourself". Transl. W. Lowrie. Princeton:

Princeton University Press, 1974. 
KREMER, M. "The Cardinal Problem in Philosophy". (pp. 143-76). In: Crary (org.). Wittgenstein and the Moral Life: Essays in Honor of Cora Diamond. MIT Press, 2007. KÜRNBERGER, F. "Literarische Herzensachen”. Wien: Rosner Verlag, 1877.

KUUSELA, O. "The Dialectic of Interpretations: Reading the Tractatus". (pp. 121-148). In: R. Read, M. A. Lavery (eds.). Beyond the Tractatus Wars: The New Wittgenstein Debate. New York: Routledge, 2011.

LUGG, A. "Wittgenstein's Tractatus: True Thoughts and Nonsensical Propositions". Philosophical Investigations, Vol. 26, Nr. 4, pp. 332-347, 2003.

MALCOLM, N. "Nothing is Hidden". Blackwell, 1986.

MCGINN, M. "Wittgenstein and Internal Relations". European Journal of Philosophy Vol. 18, Nr. 4, pp. 495-509, 2009.

. "Elucidating the Tractatus". Oxford: Clarendon Press, 2006.

"Between Metaphysics and Nonsense". Philosophical Quarterly, Vol. 50, Nr.

197, pp. 491-513, 1999.

MCGUINNESS, B. "The Supposed Realism of the Tractatus". (pp. 82-94). In: Approaches to Wittgenstein (Collected Papers). London: Routledge, 2005.

. "Wittgenstein: A Life 1889-1921". Berkeley: University of California Press,

1988.

MOORE, G. E. (1966) “Wittgenstein's Lectures in 1930-33”. In: Philosophical Papers. New York: Collier Books.

MORIS, M., DODD, J. "Mysticism and Nonsense in the Tractatus". European Journal of Philosophy, Vol. 17, pp. 247-276, 2009.

MOUNCE, H. O. “Wittgenstein's Tractatus: an Introduction”. Oxford: The University of Chicago Press, Midway Reprint Edition, 1989.

NORDMAN, A. "Wittgenstein's Tractatus". Cambridge University Press, 2005.

OSTROW, M. B. "Wittgenstein's Tractatus: A Dialetical Interpretation”. Cambridge University Press, 2002.

PEARS, D. "The False Prison Volume One". Oxford: Clarendon Press, 1987.

RHEES, R. "Discussions of Wittgenstein". Bristol: Toemmes Press, 1996.

RICKETTS, T. "Pictures, Logic, and the Limits of Sense in Wittgenstein's Tractatus". In: D. Stern, H. Sluga (eds.). The Cambridge Companion to Wittgenstein. Cambridge University Press, 1996.

PROOPS, I. "The New Wittgenstein: A Critique". European Journal of Philosophy, Vol. 9, Nr. 3, pp. 375-404, 2001.

RUSSELL, B. "The Selected Letters of Bertrand Russell: The Public Years, 19141970". Ed. N. Griffin. London: Routledge, 2002.

SULLIVAN, P. "What is the Tractatus About?". (pp. 28-41). In: M. Koelbel, B. Weiss (eds.). Wittgenstein's Lasting Significance. London: Routledge, 2004.

WHITE, R. "Throwing the Baby Out with the Ladder: On "Therapeutic" Readings of Wittgenstein's Tractatus". (pp. 22-65). In: R. Read, M. A. Lavery (eds.). Beyond the Tractatus War: The New Wittgenstein Debate. New York: Routledge, 2011.

2006.

"Wittgenstein's Tractatus Logico-Philosophicus". London: Continuum, 
WINCH, P. “The Unity of Wittgenstein's Philosophy". (pp. 1-19). In: P. Winch (ed.). Studies in the Philosophy of Wittgenstein. London: Routledge, 1969.

. "Language, Thought, and World in Wittgenstein's Tractatus". (pp. 4-17). In:

Trying to Make Sense. New York: Basic Blackwell, 1987.

WILLIAMS, M. "Nonsense and Cosmic Exile: the Austere Reading of the Tractatus". (pp. 1-27). In: M. Koelbel, B. Weiss (eds.). Wittgenstein's Lasting Significance. London: Routledge, 2004.

WITTGENSTEIN, L. (1921). "Tractatus Logico-philosophicus". Transl. McGuiness B. F. and D. Pears. London: Routledge, 2004.

. "Prototractatus". Ed. B. McGuinness. London: Routledge, 1996.

. (1921). "Tractatus Logico-Philosophicus". Transl. C. K. Ogden, with an introduction of B. Russell. New York: Dover Publications, 1999.

. "Wittgenstein's Lectures Cambridge, 1930-32". From the notes of John King and Desmond Lee (ed.). University of Chicago Press, 1989.

. "Wittgenstein and the Vienna Circle". Ed. B. McGuinness, Transl. J. Schulte.

Oxford: Blackwell, 1979.

. "Philosophical Remarks". Transl. R. White and R. Hargreaves. Chicago: The University of Chicago Press, 1975.

. "Notebooks 1914-16". 2nd edition. Transl. G. E. M. Anscombe, Eds. Anscombe and Von Wright. Chicago: The University of Chicago Press, 1979.

. "Wittgenstein in Cambridge: Letters and Documents 1911-1951". Ed. B. McGuiness. Oxford: Willey-Blackwell, 2012.

, "Ludwig Wittgenstein: Public and Private Occasions". Eds. J. C. Klagge and A. Nordmann. New York: Rowman \& Littefield Publishers, 2003.

, Wittgenstein's Nachlass: The Bergen Electronic Edition. Oxford: Oxford University Press, 2000.

. "Notes on Logic". (pp. 93-107). In: Notebooks 1914-16. 2nd edition. Transl.

G. E. M. Anscombe, Eds. Anscombe and Von Wright. Chicago: The University of Chicago Press, 1979.

. "Notes Dictated to Moore in Norway". (pp. 108-119). In: Notebook 191416. 2nd edition. Transl. G. E. M. Anscombe, and Eds. Anscombe and Von Wright. Chicago: The University of Chicago Press, 1979.

. "Briefe an Ludwig von Ficker". Eds. G. H. Von Wright and W. Methlagl. Salzburg: Otto Mueller Verlag, 1969.

. "Some Remarks on Logical Form". Proceedings of the Aristotelian Society, Vol. 9, pp. 162-171, 1929. 